\title{
Prolonged control of replication-competent dual- tropic human immunodeficiency virus-1 following cessation of highly active antiretroviral therapy
}

Maria Salgado', S Alireza Rabi ${ }^{1}$, Karen A O'Connell', Robert W Buckheit III', Justin R Bailey ${ }^{1}$, Amina A Chaudhry', Autumn R Breaud ${ }^{2}$, Mark A Marzinke², William Clarke², Joseph B Margolick ${ }^{3}$, Robert F Siliciano ${ }^{1,4}$ and Joel N Blankson ${ }^{1 *}$

\begin{abstract}
Background: While initiation of highly active antiretroviral therapy (HAART) during primary HIV-1 infection occasionally results in transient control of viral replication after treatment interruption, the vast majority of patients eventually experience a rebound in plasma viremia.

Results: Here we report a case of a patient who was started on HAART during symptomatic primary infection and who has subsequently maintained viral loads of $<50$ copies $/ \mathrm{mL}$ for more than nine years after the cessation of treatment. This patient had a high baseline viral load and has maintained a relatively high frequency of latently infected $C D 4^{+} T$ cells. In addition, he does not have any known protective HLA alleles. Thus it is unlikely that he was destined to become a natural elite controller or suppressor. The mechanism of control of viral replication is unclear; he is infected with a CCR5/CXCR4 dual-tropic virus that is fully replication-competent in vitro. In addition, his spouse, who transmitted the virus to him, developed AIDS. The patient's CD4 ${ }^{+} \mathrm{T}$ cells are fully susceptible to HIV-1 infection, and he has low titers of neutralizing antibodies to heterologous and autologous HIV-1 isolates. Furthermore, his $\mathrm{CD}^{+} \mathrm{T}$ cells do not have potent HIV suppressive activity.

Conclusion: This report suggests that some patients may be capable of controlling pathogenic HIV-1 isolates for extended periods of time after the cessation of HAART through a mechanism that is distinct from the potent cytotoxic T lymphocyte (CTL) mediated suppression that has been reported in many elite suppressors.
\end{abstract}

Keywords: HIV-1, elite suppressor, elite controller, viral replication

\section{Background}

HIV-1 infection results in extensive viral replication and progressive $\mathrm{CD} 4^{+} \mathrm{T}$ cell depletion in the vast majority of patients. However, rare subjects, known as elite controllers or suppressors (ES), spontaneously control viral replication without antiretroviral treatment [1]. The mechanisms involved in elite control are not fully understood, but some ES appear to be infected with fully replication-competent virus [2-5] that continues to

\footnotetext{
* Correspondence: jblanks@jhmi.edu

'Department of Medicine, Johns Hopkins University School of Medicine, Baltimore, Maryland 21287, USA

Full list of author information is available at the end of the article
}

evolve during chronic infection [6-8]. Thus infection with attenuated virus does not appear to be a common cause of elite control. In contrast, many studies looking at host factors have shown that the HLA-B*27 and 57 alleles are overrepresented in ES [9-14]. This has strongly suggested a role for $\mathrm{CD}^{+} \mathrm{T}$ cell responses in elite control, and indeed, potent HIV-specific CD ${ }^{+} \mathrm{T}$ cell responses [15-17] that are capable of inhibiting viral replication $[18,19]$ have been documented in many ES.

It is not clear whether it will be possible to elicit similar levels of immune control in patients with progressive HIV-1 disease. However, some studies have suggested that rare individuals who are treated early in primary

\section{C) Biomed Central}


infection with highly active antiretroviral therapy (HAART) are able to control viral replication when therapy is discontinued. Rosenberg and colleagues demonstrated that five of eight patients who were treated before or shortly after seroconversion were able to suppress HIV RNA levels to below 500 copies/mL for a median of 6.5 months after therapy was interrupted [20]. However, a follow up study showed that this control was of limited duration as only three of 14 patients who started HAART during primary infection maintained viral loads of $<5000$ copies/mL two years after treatment interruption [21]. In another study, a patient who was started on HAART a month after seroconversion was treated for four years prior to a treatment interruption which resulted in a rapid rebound in viremia. HAART was reinitiated and ultra-low doses of interleukin-2 $\left(1.2 \mathrm{mIU} / \mathrm{m}^{2} /\right.$ day $)$ were added to the regimen. Interestingly, he maintained viral loads of $<50$ copies/mL for 14 months after both HAART and IL-2 were discontinued [22]. In a recent study, five of thirtytwo patients treated during primary HIV-1 infection maintained control of viral replication for more than six months after treatment was interrupted [23]. While this phenomenon is not routinely seen with early treatment [24-26], these cases strongly suggest that the immune system can be manipulated to control HIV-1 replication in some patients. Thus, this could be the basis for the design of a successful therapeutic vaccine.

We present a case of a patient infected with a replication-competent, dual-tropic HIV-1 isolate who was started on treatment during primary infection. He has maintained stable CD4+ T cell counts and viral loads of $<50$ copies/ml for more than nine years since HAART was discontinued. To our knowledge, this represents the longest period of control of HIV-1 replication in a patient after the cessation of treatment. We performed detailed analyses of the patient's viral isolates and looked at multiple aspects of his HIV-specific immune response. While no clear mechanism of immune control was identified, this case suggests that long term control of pathogenic HIV-1 isolates is possible in some patients who were destined to become chronic progressors (CP).

\section{Results \\ Patients}

Patient 169 is a 57 year old male who was diagnosed with primary HIV-1 infection when he admitted to the intensive care unit at Johns Hopkins Hospital in 1999 with severe HIV-1 meningoencephalitis that resulted in intubation for airway protection [27]. He was found to have an indeterminate Western blot (only bands to p24 were present) and an HIV-1 viral load of $>750,000$ copies/mL. He reported having tested negative for HIV1 two years prior to admission. He was enrolled into the
Acute Infection and Early Disease Research Program (AIEDRP) study and started on a regimen of zidovudine, lamivudine, and indinavir within 48 hours of admission. This regimen was changed to abacavir, lamivudine and efavirenz at week four and by week 16 , his viral load was $<50$ copies $/ \mathrm{ml}$. He stopped taking his antiretrovirals at week 36 for a 2 week period, and his viral load rebounded to 22,000 copies/ $\mathrm{ml}$. The same regimen was re-initiated, and he was adherent until week 92 at which time he stopped taking all of the antiretroviral drugs. His $C D 4^{+} \mathrm{T}$ cell count, which was 412 cell/ $\mu \mathrm{L}$ at the time of diagnosis, has been stable at greater than 1000 cells $/ \mu \mathrm{L}$ over the last five years, and his viral load, which has been consistently less than 50 copies $/ \mathrm{ml}$ since the discontinuation of HAART, was measured at 1 copy $/ \mathrm{mL}$ in 2011 using a highly sensitive single copy assay [28,29] (Figure 1). The patient was incarcerated between 2004 and 2005, and medical records confirmed that he was not on antiretroviral therapy at this point. Furthermore, qualitative testing for antiretroviral drugs on plasma samples from 2009, 2010 and 2011 was performed to rule out surreptitious use of antiretroviral therapy. All samples were negative whereas nevirapine and lamivudine were detected in a plasma sample from his spouse.

The patient's spouse was diagnosed with HIV-1 infection 3 years before subject 169 was admitted with acute retroviral syndrome. Her $\mathrm{CD} 4^{+} \mathrm{T}$ cell count nadir was 84 cells $/ \mu \mathrm{L}$, and her baseline viral load prior to the initiation of HAART was 122,000 copies/ml.

\section{Patient 169 has a high frequency of HIV-1 infected $\mathrm{CD}^{+} \mathrm{T}$ cells}

In order to determine whether the patient was infected with a defective virus and whether his spouse transmitted the virus to him, we amplified virus from a plasma sample from the time of diagnosis. In addition, virus was cultured from $\mathrm{CD} 4^{+} \mathrm{T}$ cells isolated from PBMCs obtained from the patient and his spouse in 2010. The frequency of latently infected resting $\mathrm{CD} 4^{+} \mathrm{T}$ cells in patient 169 was 1.61 infectious units per million, which is more than a log higher than the frequency found in our cohort of ES [3] and similar to the frequencies found in chronic progressors on suppressive HAART regimens $[30,31]$.

\section{Patient 169 is infected with fully replication-competent, dual-tropic virus}

We next analyzed the fitness of isolates obtained from patient 169 and his spouse. For patient 169, full genome sequencing of replication-competent virus cultured from 1999 plasma and three independent replication-competent isolates obtained from CD4 $4^{+} \mathrm{T}$ cells in 2010 was performed. One of the isolates from 2010 (2B) was identical to the 1999 isolate with the exception of a single 


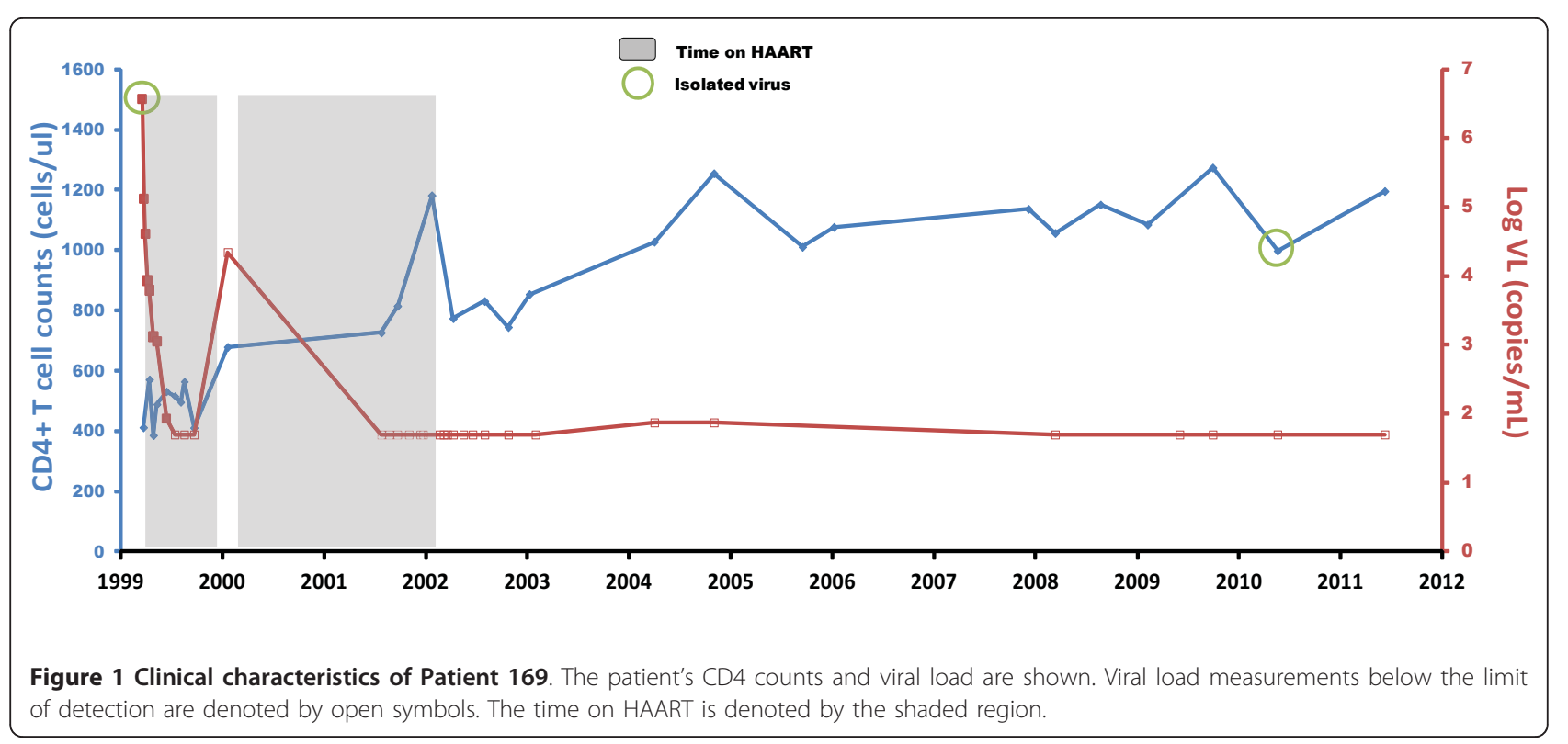

nucleotide difference in the HIV-1 LTR. The two other isolates from $2010(1 \mathrm{~A}, 1 \mathrm{~B})$ were identical although they were isolated from independent culture wells. The differences between the identical 2010 isolates and the 1999 isolate are summarized in Table 1. For the patient's spouse, full genome sequencing of two independent isolates cultured from her resting $\mathrm{CD} 4^{+} \mathrm{T}$ cells in 2010 was performed. No large deletions were found in any gene and no drug resistance mutations were found in any of the isolates obtained from either patient. Phylogenetic analysis of the env gene showed that the isolates from 169 and his spouse were more closely related to each other than to any other isolate in the Los Alamos database, confirming that the two patients were a transmission pair [Figure 2].

Table 1 Differences in sequence of replication-competent 1999 and 2010 isolates.

\begin{tabular}{lcc}
\hline & Differences between Pt-169 1999 and 2010-1A/1B isolates \\
\cline { 2 - 3 } & Nucleotides & Amino Acids \\
\hline LTR & 2 & $\Delta 6^{*}$ \\
\hline Gag & $\Delta 18^{*}$ & 2 \\
\hline Pol & 2 & 0 \\
\hline Vif & 0 & 1 \\
\hline Vpr & 1 & 0 \\
\hline Vpu & 0 & $1, \Delta 7(\mathrm{~V} 4)^{*}$ \\
\hline Env & $2, \Delta 21(\mathrm{~V} 4)^{*}$ & 1 \\
\hline Nef & 1 & 18 \\
\hline Total & 47 & \\
\hline
\end{tabular}

Isolate 2B from 2010 is identical to the 1999 isolate with the exception of a single nucleotide in the LTR. Isolates $1 \mathrm{~A}$ and $1 \mathrm{~B}$ are identical to each other.

* The triangle denotes deletions in the 2010-1A/1B isolates.
Sequence analysis of the env gene suggested that all isolates cultured from both patients were CXCR4- tropic (data not shown). To confirm this, we amplified and cloned the env gene from the 1999 and 2010 isolates from patient 169, and made GFP-expressing NL4-3 pseudotyped virus as previously described [32]. Infection studies were then performed with GHOST cells expressing CCR5 and/or CXCR4. As shown in Figure 3A, pseudotyped virus containing env from 1999 and 2010 was able to infect GHOST cells expressing either coreceptor, demonstrating that each viral clone was dualtropic (Figure 3A).

We next compared the replication capacity of virus cultured from patient 169 to that of CCR5-tropic (Ba-L) and CXCR4-tropic (IIIB) laboratory isolates. As shown in Figure 3B, the isolates from 1999 and 2010 replicated as well as IIIB in MT-2 cells whereas Ba-L did not replicate in these cells, which do not express the CCR5 co-receptor. In primary $\mathrm{CD}^{+} \mathrm{T}$ cells, the two isolates from Patient 169 replicated as well as Ba-L. Thus control of viral replication in this patient was not due to infection with an attenuated virus, and viral fitness was stable over time.

\section{Patient 169 does not have known genetic factors that contribute to the control of viral replication}

Having ruled out viral attenuation, we focused on host factors as potential causes of the observed virologic control. Heterozygosity for the 32 base pair deletion in CCR5 has been associated with slow HIV-1 progression $[33,34]$. This gene was thus analyzed by PCR, and patient 169 was determined to have two wild type CCR5 alleles. The most consistent finding in different cohorts of ES has been the over-representation of protective 
A)

$\overbrace{* \quad 150 * \text { * } 150}^{\text {* }}$

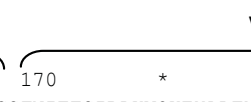

V2

190

230

CONSENSUS B EnV: CTDLMNATNTNTTIIYRW-----------RGEIKNCSFNITTSIRDKVQKEYALFYKLDVVPIDNDNTSYRLISCNTSVITQACPKVSFEPIPIHYCAPAGFA : 92

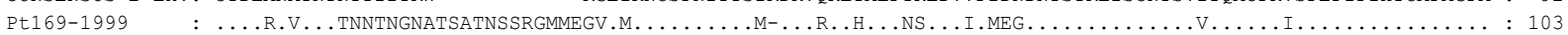

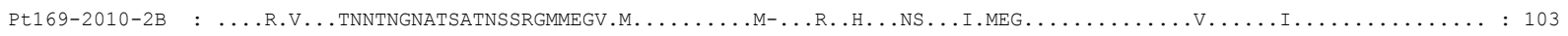

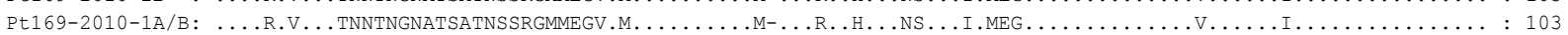

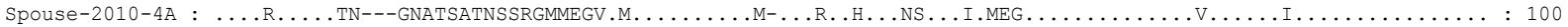

* $250 \quad * \quad 270$ * 290 V3

CONSENSUS B ENV: ILKCNDKKFNGTGPCTNVSTVQCTHGIRPVVSTQLLLNGSLAEEEVVIRSENFTDNAKTIIVQLNESVEINCTRPNNNTRKSIHIGPGRAFYTTGEIIGDIRQA : 196

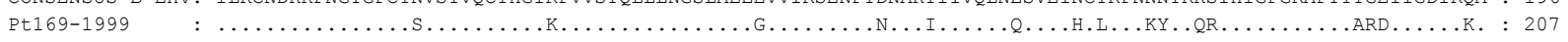

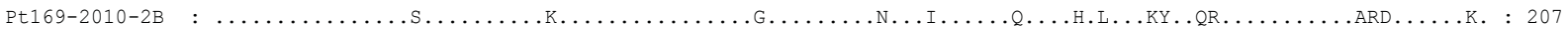

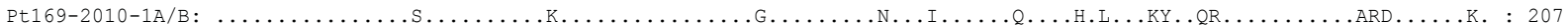

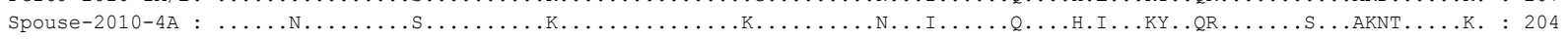
V4
350
370
390

V4

CONSENSUS B EnV: HCNISRAKWNNTLKQIVKKLREQFGNKTIVFNQSSGGDPEIVMHSFNCGGEFFYCNTTQLFNSTWNGTW------NNTEGNITLPCRIKQIINMWQEVGKAMYA : 294

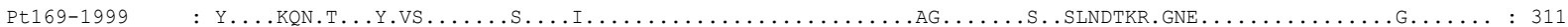

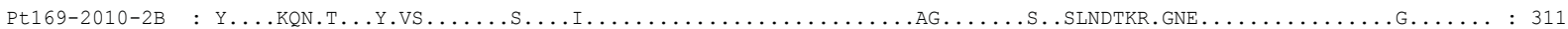

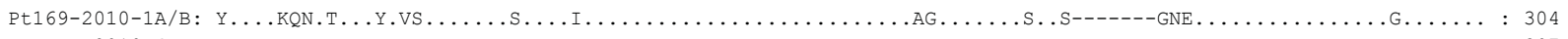

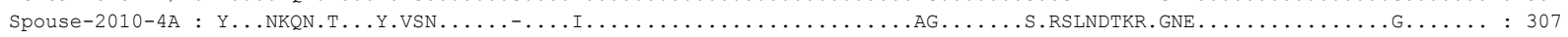

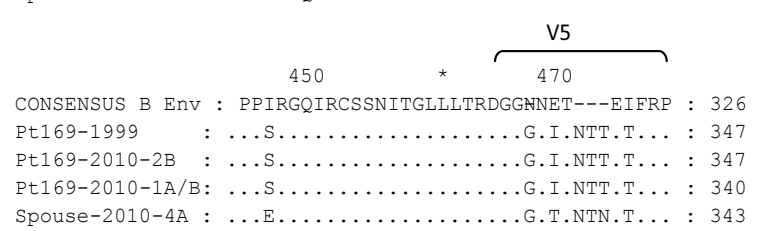

B)

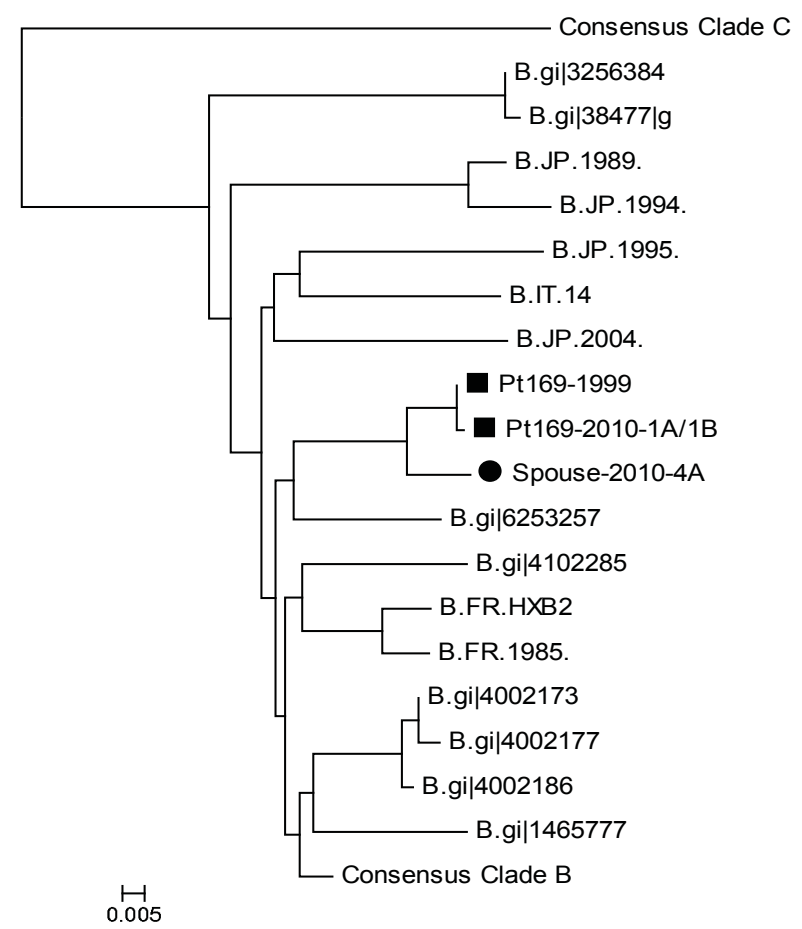

Figure 2 Phylogenetic Analysis: An alignment of the variable regions of env is shown for replication-competent isolates obtained from Patient 169 and his spouse. Numbering is from the first amino acid in gp120. (A). The sequences are also compared to other Clade B sequences(B). Phylogenies were estimated by using a classical approach, functioning under a maximum-likelihood (ML) optimality criterion.

HLA alleles such as HLA-B*27 and B*57 [9-14,35,36]. In addition, genome wide association studies have documented a protective single nucleotide polymorphism
(SNP) in the HLA-C promoter [35,36]. Furthermore, HLA-Bw4-80Ile alleles have been shown to be associated with slowly progressive disease when inherited in 


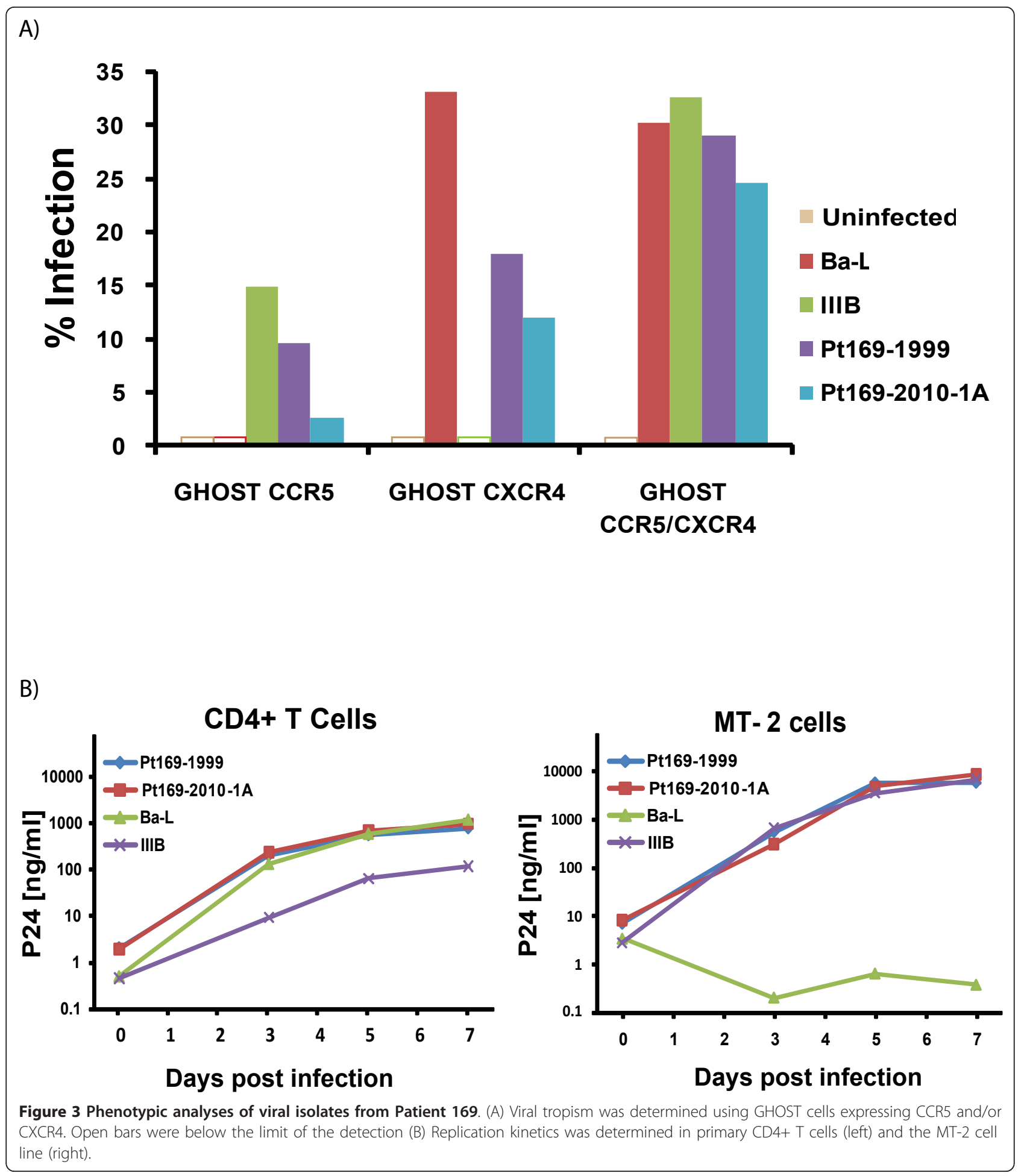

conjunction with the KIR3DS1 and/or KIR3DL1 natural killer cell receptor alleles [37,38]. Patient 169 does not have an HLA-Bw4-80Ile allele or any other HLA allele that has been previously associated with attenuated HIV-1 disease. He also does not have the protective C/ C HLA-C SNP (Table 2).
$\mathrm{CD}^{+} \mathrm{T}$ cells from Patient 169 are fully susceptible to infection

Some studies $[39,40]$ have suggested that ES CD4 ${ }^{+} \mathrm{T}$ cells that have been activated ex vivo are resistant to viral infection while others have shown that unstimulated $\mathrm{CD} 4^{+} \mathrm{T}$ cells from these patients are fully susceptible to viral entry 
Table 2 Analysis of genetic factors associated with protection in HIV-1 infection

\begin{tabular}{ll}
\hline & Genetic factors \\
\hline Factor & Genotype \\
\hline CCR5 & wild type \\
\hline HLA-A & ${ }^{*} 3001,{ }^{*} 6801$ \\
HLA-B & ${ }^{*} 4201{ }^{*}$ \\
HLA-C & ${ }^{*} 0602,{ }^{*} 1701$ \\
\hline HLA C SNP (rs9264942) & T/C \\
\hline
\end{tabular}

and productive infection $[41,42]$. In order to determine whether $\mathrm{CD}^{+}{ }^{+} \mathrm{T}$ cells from patient 169 were resistant to infection, we purified primary $\mathrm{CD}^{+} \mathrm{T}$ cells from 169 and five HIV-1 seronegative donors and infected them directly ex vivo by spinoculation with CCR5 (Ba-L) and CXCR4 (NL4-3) tropic isolates as previously described. As shown in Figure 4, CD4 ${ }^{+} \mathrm{T}$ cells from 169 were as susceptible to infection with both types of isolates as were the $\mathrm{CD} 4^{+} \mathrm{T}$ cells from the seronegative donors. In order to determine if spinoculation was masking subtle differences in the susceptibility to infection, we infected $\mathrm{CD}^{+}{ }^{+} \mathrm{T}$ cells with CXCR4-tropic virus without spinoculation [41] and again found that $\mathrm{CD}_{4}^{+} \mathrm{T}$ cells from patient 169 were fully susceptible to infection. We also looked at susceptibility to infection with serial dilutions of both lab strains and a pseudotyped virus containing dual tropic envelope that was amplified from the patient in 1999. In all cases, patient 169 's cells were found to be as susceptible to infection as cells from HIV-negative donors.

\section{Patient 169 has low titers of HIV-specific neutralizing antibodies}

To determine whether a robust humoral response was playing a role in the control of viral replication, we compared reciprocal IC50 titers of neutralizing antibodies $(\mathrm{Nab})$ in patient 169 to titers in viremic patients and ES as previously described [43]. Patient 169 had the lowest titers of Nab to laboratory strain SF162 Env as shown in Figure 5. To determine how well the patient neutralized autologous virus, we measured titers of Nab to pseudotyped virus expressing Env cloned from the 1999 and 2010 replication-competent isolates. His reciprocal IC 50 titers of $\mathrm{Nab}$ to autologous Env from 1999 was 1:195 which is comparable to the titers seen in ES, but lower than the titers seen in viremic patients [43]. In contrast, his $\mathrm{Nab}$ titer to contemporaneous Env was $>1$ : 4 (Figure 5B). Thus it appears that neutralizing antibodies were not the cause of control of viral replication in this patient.

\section{Characteristics of the HIV-specific $\mathrm{CD}^{+} \mathrm{T}$ cell response in Patient 169}

Many ES have been found to possess potent HIV-specific $\mathrm{CD}^{+} \mathrm{T}$ cell activity [16-19]. We thus looked at CD8
${ }^{+} \mathrm{T}$ cell responses in Patient 169. An ELISPOT assay was performed following stimulation with Gag and Nef peptides. As shown in Figure 6, two independent nonoverlapping epitopes were targeted in Nef, and and six such epitopes were targeted in Gag. Escape mutations in certain Gag epitopes have been associated with viral attenuation [44-46], and we therefore examined sequences in targeted epitopes to look for signs of virologic escape. A comparison of the sequences from the 1999 and 2010 isolates showed an R18G substitution in a Nef epitope and a G17W substitution in a Gag epitope in isolates $1 \mathrm{~A}$ and $1 \mathrm{~B}$. Both substitutions were absent in isolate $2 \mathrm{~B}$, and thus even if these mutations caused a reduction in viral fitness in some isolates, escape mutations would not explain virologic control in this patient.

To determine whether $\mathrm{CD}^{+} \mathrm{T}$ cells were involved in the direct control of viral replication, we attempted to culture autologous virus from Patient 169 with and without the depletion of $\mathrm{CD}^{+} \mathrm{T}$ cells. As shown in Figure 7A, virus culture was successful only when $\mathrm{CD}^{+} \mathrm{T}$ cells were depleted, but the same phenomenon was seen in chronic progressors who had substantial levels of viremia and in patients on suppressive HAART regimens. There was no viral outgrowth from ES CD4 ${ }^{+} \mathrm{T}$ cells consistent with the low frequency of infected $\mathrm{CD}_{4}{ }^{+} \mathrm{T}$ cells in these patients [3]. We next compared the respective abilities of $\mathrm{CD}^{+} \mathrm{T}$ cells from Patient 169 and ES in HIV-1 inhibition assays in which pseudotyped virus was used to superinfect autologous $\mathrm{CD} 4^{+} \mathrm{T}$ cells. As shown in Figure $7 \mathrm{~B}$, while primary $\mathrm{CD}^{+} \mathrm{T}$ cells from most ES caused a significant reduction in virus replication, $\mathrm{CD}^{+} \mathrm{T}$ cells from Patient 169 had very little effect in this assay.

\section{Discussion}

We present here a patient who has controlled HIV-1 replication for more than nine years after the cessation of HAART. While some studies have reported that initiation of HAART during primary infection can lead to the control of viral replication once therapy is discontinued, most of these patients eventually experienced a rebound in viremia [21,22]. To our knowledge, the nine years of control seen in patient 169 is the longest period of control reported in a patient who was treated in primary infection and who subsequently underwent treatment interruption. We extend prior studies by performing full genome sequence analysis and phenotypic studies of viral isolates obtained at the time of infection and eight years after the cessation of HAART. We show that Patient 169 was infected by virus from a patient with AIDS, and we demonstrate that the viral isolates from patient 169 are dual-tropic and replication-competent, which makes it unlikely that an attenuated virus was transmitted. It should be noted that 


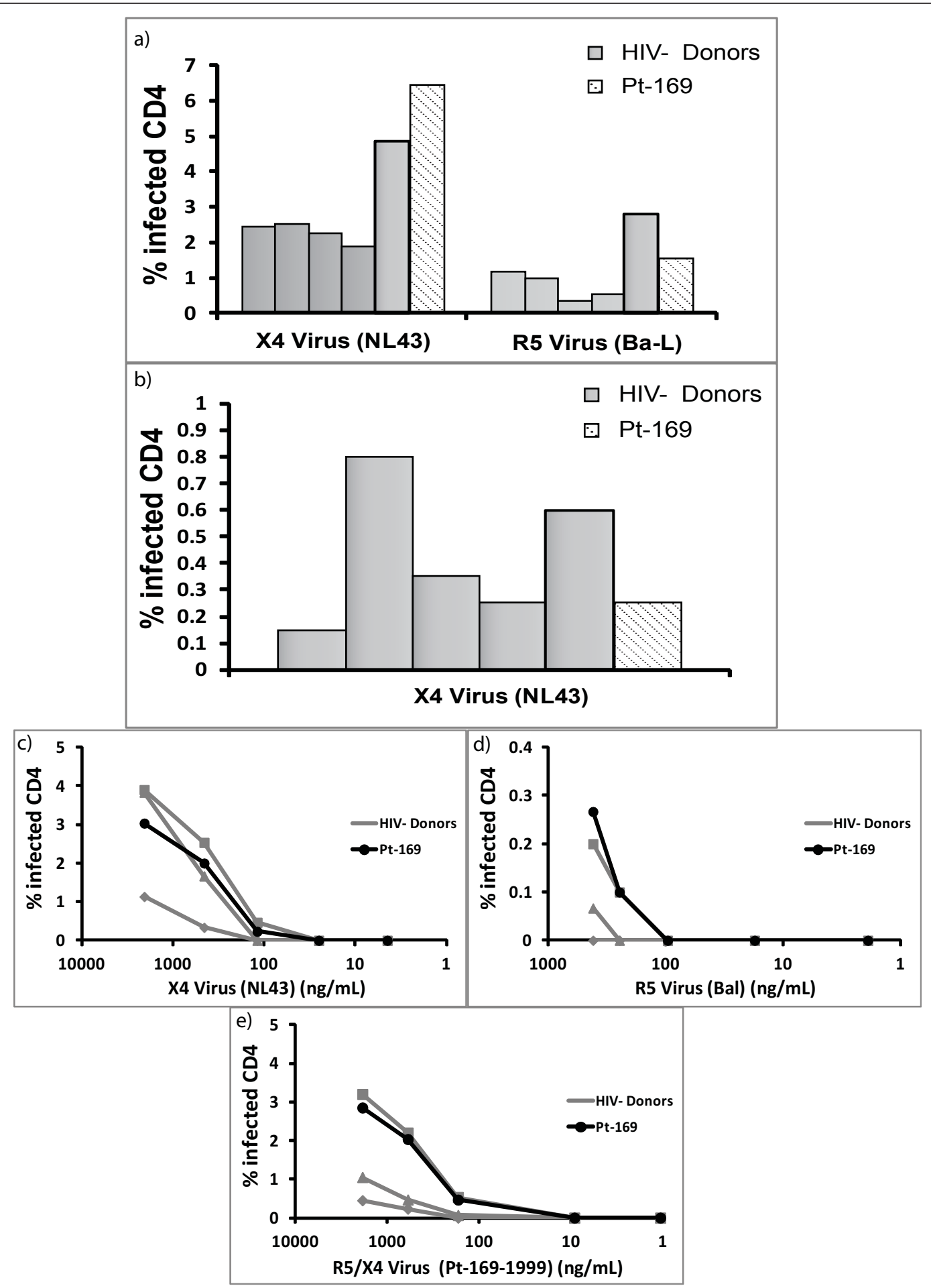

Figure 4 CD4+ T cell susceptibility assay. CD4+ T cells from five healthy donors (grey columns) and Patient 169 (shaded column) were infected with CCR5 tropic (Bal) and CXCR4 tropic (NL43) pseudotypevirus by spinoculation (A) or with NL43pseudotype virus without

spinoculation (B). Infection with serial dilutions of CXCR4-tropic (C), CCR5-tropic (D) and dual-tropic virus (E) was also performed by spinoculation. The percent of infected cells (GFP positive) are shown. 


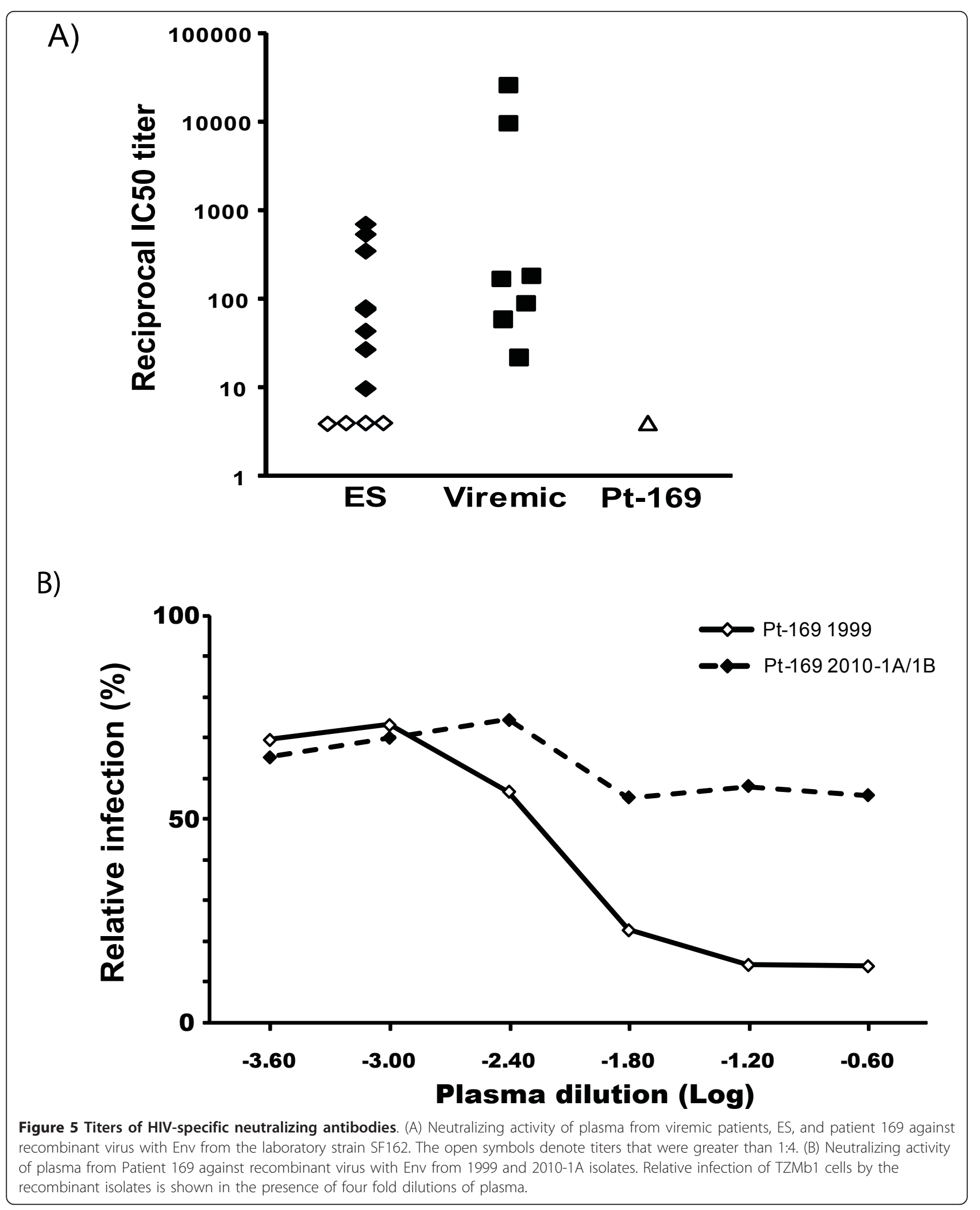




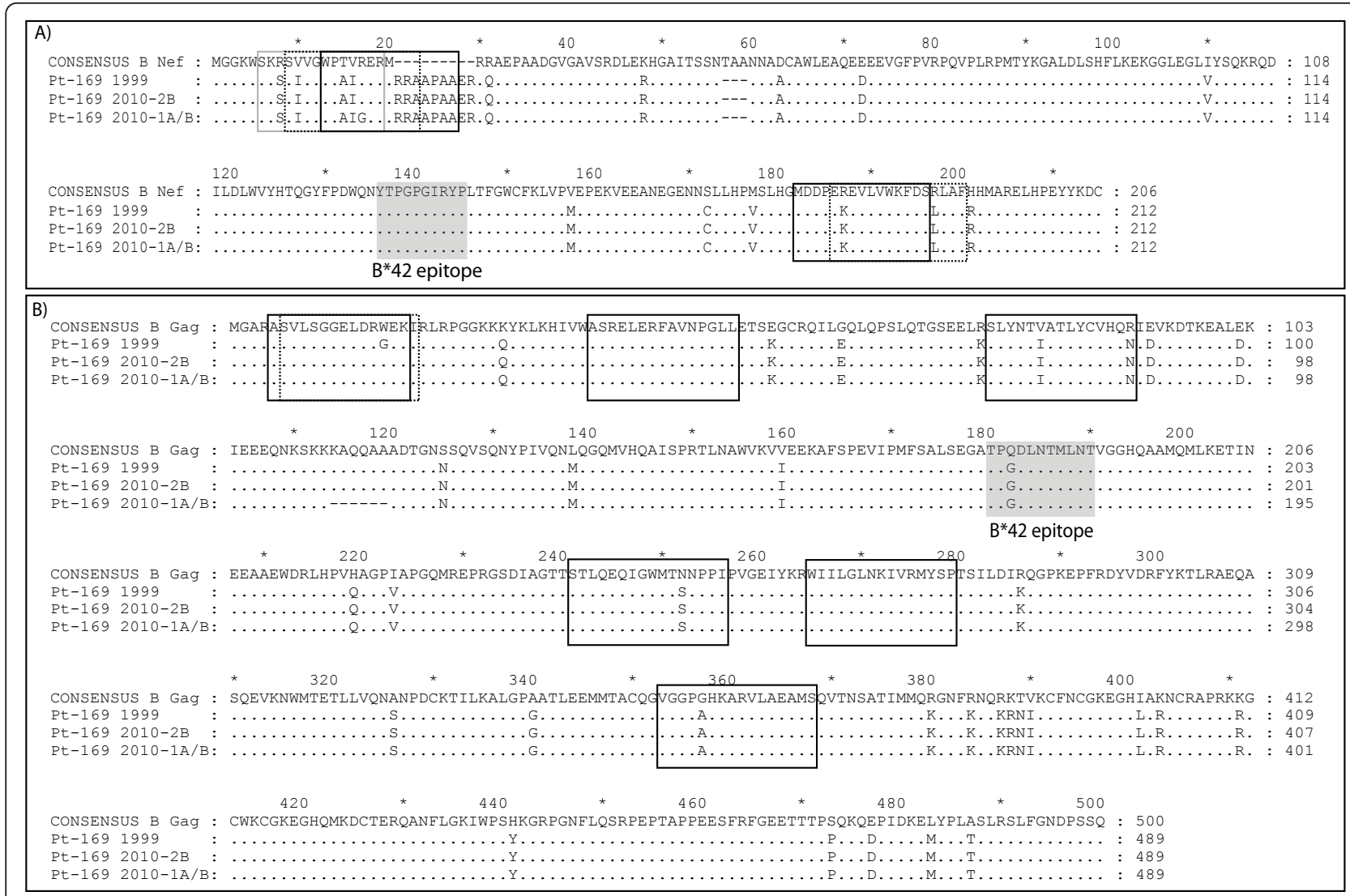

Figure 6 CD8+ T cell epitope analysis. Epitopes in Nef (A) and Gag (B) targeted by CD8+ T cells as determined by an IFN-g ELISPOT assay using overlapping 15 mers. Open boxes represent actual peptides targeted in the assay whereas the shaded boxes represent predicted optimal HLA-B*42 restricted epiotpes which were not targeted.

infection with dual-tropic virus is associated with more rapid progression than infection with CCR5-tropic virus $[47,48]$. Thus the long term control seen in this patient is even more remarkable.

We hypothesized that the patient's virus may have developed drug resistance mutations or escape mutations that led to viral attenuation later in his disease course. However sequence analysis did not reveal any drug resistance mutations, and potential escape mutations in Gag and Nef were seen in only some isolates. While it is possible that escape mutations in other viral genes caused a reduction in viral fitness, the fact that isolates obtained from 2010 replicated as well in vitro as viral isolates present during primary infection makes this unlikely.

We considered the possibility that this patient was destined to become a natural ES. However several observations suggest that this is not the case. He had a viral load of $>750,000$ copies $/ \mathrm{mL}$ and was very symptomatic during seroconversion. Studies have shown that patients with severe acute retroviral syndrome have a more rapid rate of disease progression [49]. In contrast, natural ES tend to have limited symptoms and low viral loads during primary infection [50-52]. ES also invariably have extremely low frequencies of latently infected $\mathrm{CD} 4^{+} \mathrm{T}$ cells [3] whereas Patient 169 had a very large number of HIV-1 infected $\mathrm{CD} 4^{+} \mathrm{T}$ cells during primary infection [27], and his current frequency of latently infected cells is currently similar to that seen in patients with progressive disease on HAART. Finally, he did not have any of the HLA alleles that are overrepresented in ES.

We show here that $\mathrm{CD} 4^{+} \mathrm{T}$ cells from Patient 169 are fully susceptible to infection and that he had very low titers of neutralizing antibodies to heterologous and autologous virus. Interestingly, depletion of $\mathrm{CD}^{+} \mathrm{T}$ cells resulted in efficient outgrowth of virus from $\mathrm{CD} 4^{+}$ $\mathrm{T}$ cells. While this suggests that $\mathrm{CD} 8^{+} \mathrm{T}$ cells are playing a role in the control of viral replication, it is unlikely to be the only mechanism involved as $\mathrm{CD}^{+} \mathrm{T}$ cells from patients with progressive disease were also effective at preventing outgrowth of autologous virus. In contrast, $\mathrm{CD}^{+} \mathrm{T}$ cells from Patient 169 were not as effective as those from ES at inhibiting replication of recombinant virus carrying GFP. Thus it appears that this patient is controlling replication of pathogenic dual-tropic virus by 


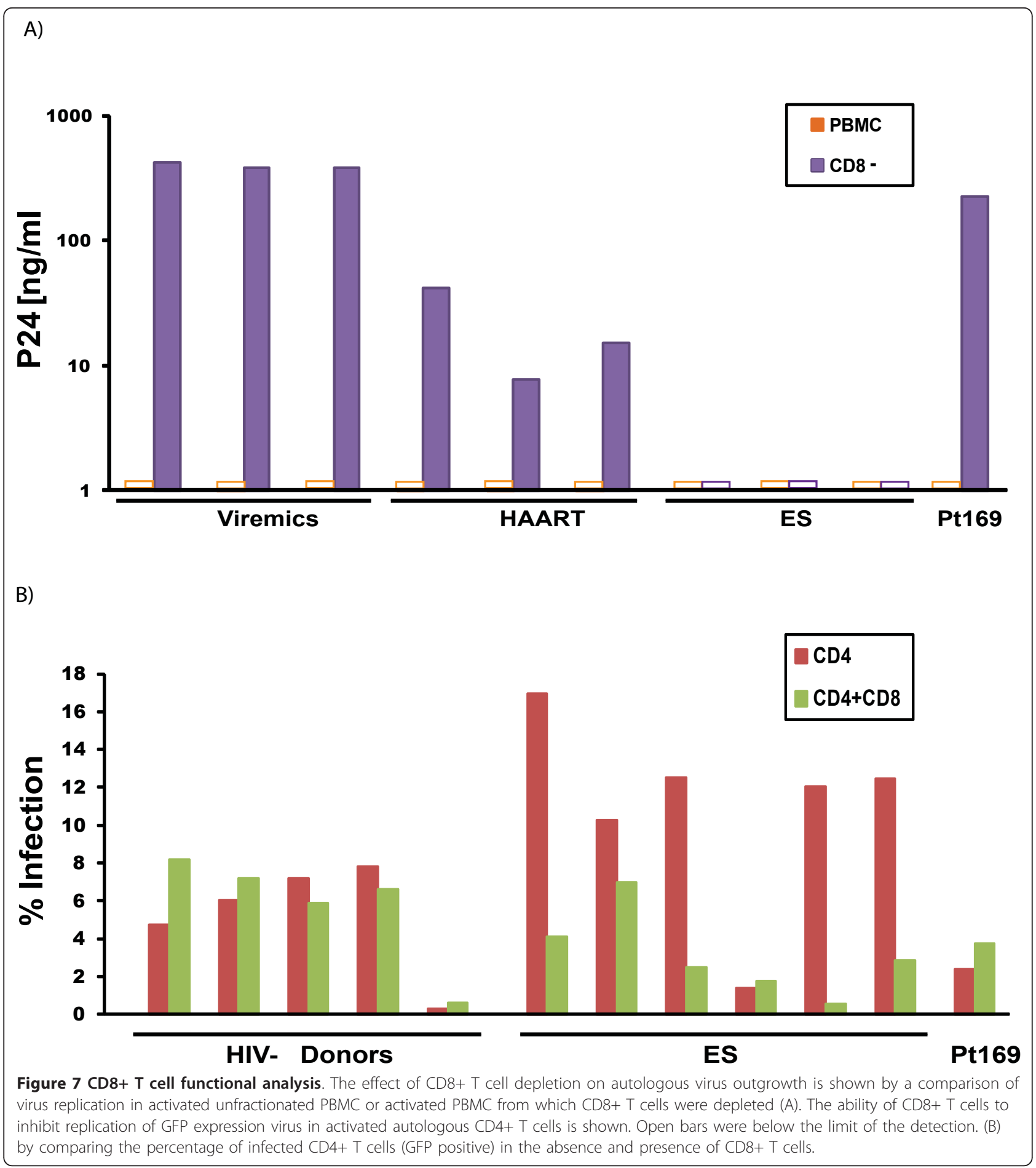

a mechanism that is distinct from the $\mathrm{CD}^{+} \mathrm{T}$ cell mediated control that is seen in many ES. This unknown mechanism may be similar to the mechanisms present in ES who do not possess protective HLA alleles or potent HIV-specific $\mathrm{CD}^{+} \mathrm{T}$ cell responses $[9,13,53]$, but it is still unique in that control is being maintained over a much larger number of infected CD4+ T cells in Patient 169.

\section{Conclusions}

The data presented here suggest that early treatment in some patients infected with fully pathogenic virus can 
lead to control of viral replication for extended periods of time. Understanding the mechanisms involved in this control may lead to vaccine development and effective immunotherapy in patients with progressive disease.

\section{Availability of supporting data}

The data sets supporting the results of this article are available in the Gen Bank repository (accession numbers JN599164 and JN599165)

\section{Methods}

\section{Virus Isolation and Sequence Analysis}

Culture of replication-competent virus from $\mathrm{CD} 4^{+} \mathrm{T}$ cells was performed as previously described [3]. Replicationcompetent virus from 1999 was obtained by spinoculating $\mathrm{CD}_{4}^{+} \mathrm{T}$ cells from an uninfected donor with the patient's plasma. Full genome sequence analysis of viral isolates was performed as previously described [3]. Classical, maximum likelihood and Bayesian phylogenetic analysis were performed as described previously [7].

\section{Antiretroviral drug testing}

$100 \mu \mathrm{l}$ of patient serum were treated with $300 \mu \mathrm{l}$ of cold acetonitrile, stored at $-20^{\circ} \mathrm{C}$ for 20 minutes and subsequently centrifuged at $12,000 \times \mathrm{rpm}$ for 5 minutes. Specimen supernatants were evaporated to dryness and reconstituted with $100 \mu \mathrm{l}$ water. $10 \mathrm{uL}$ of each treated sample were injected onto the liquid chromatography system equipped with Transcend pumps (Thermo Fisher Scientific) for analytical separation. The chromatographic run began with 60 seconds of $5 \%$ methanol containing $10 \mathrm{mM}$ ammonium acetate (mobile phase $\mathrm{B}$ ), followed by a 10 minute ramp to $95 \%$ B. Analytes were eluted from a Hypersil Gold $50 \times 2.1 \mathrm{~mm} ; 3 \mu \mathrm{m}$ particle size HPLC column (ThermoFisher Scientific) during this gradient and the column was washed for 60 seconds with 2:2:1 acetonitrile:isopropanol:acetone and re-equilibrated with $5 \%$ mobile phase B for 180 seconds. Analytes were detected over a 14.9 minute run using the Exactive Orbitrap mass analyzer (Thermo Fisher Scientific) with a heated electrospray ionization (HESI) source. The source parameters were as follows: sheath gas: 40 , auxillary gas: 10 , sweep gas: 0 , spray voltage: $3.5 \mathrm{kV}$, capillary temperature: $270{ }^{\circ} \mathrm{C}$, capillary voltage: $60 \mathrm{~V}$, tube lens voltage: $120 \mathrm{~V}$, skimmer voltage: $15 \mathrm{~V}$, heater temperature: $350{ }^{\circ} \mathrm{C}$. The mass spectrometer method included two positive-mode scan events: one full scan event with ultra-high resolution (100000@ $1 \mathrm{~Hz})$ and one in-source collision-induced dissociation (CID) event with enhanced resolution $(25000 @ 4 \mathrm{~Hz})$ and collision energy of $45 \mathrm{eV}$. Both scan events were programmed for 100 ms maximum inject time and balanced ACG targets. The analytical method was found to have a limit of detection of $<20 \mathrm{ng} / \mathrm{ml}$ for amprenavir, atazanavir, darunavir, efavirenz, emtricitabine, indinavir, lamivudine, lopinavir, nelfinavir, nevirapine, ritonavir, saquinavir, tenofovir and tipranavir. Positive identification was determined by exact mass detection at 5 ppm discrimination, analyte retention time and identification of mass transitions when possible.

\section{Viral Tropism assay}

RFP expressing recombinant pseudotype virus was made with env genes amplified from 1999 and 2010 isolates. These viruses were used to infect GHOST cell lines transfected with CCR5 and/or CXCR4 (obtained from the NIH AIDS Research and Reference Program) and the percentage of RFP positive cells was determined in triplicates on day three. GHOST cells express low levels of endogenous CXCR4 and therefore infection of cells transfected with CCR5 alone was performed in the presence of the CXCR4 antagonist AMD 3100 at a dose of $1 \mathrm{uM}$ (obtained from the NIH AIDS Research and Reference Program).

\section{Viral Fitness Assay}

Viral fitness was analyzed as described previously [3]. PBMCs from healthy donors were activated for two days with IL-2 and PHA. CD4 ${ }^{+} \mathrm{T}$ cells were isolated (MACS, $\mathrm{CD}^{+} \mathrm{T}$ cell isolation Kit) and infected by spinoculation [54] $(1200 \times \mathrm{g}$ for 2 hours) with equal quantities (200 $\mathrm{ng} / \mathrm{mL}$ ) of p24 from primary patient isolates, or with Ba-L or IIIB laboratory HIV-1 strains as controls. Supernatant samples were taken over the course of 7 days. Viral replication was quantified using p24 ELISA (Perkin Elmer).

\section{Genetic Polymorphisms}

HLA-A, B, and C allele identification was performed at the Johns Hopkins University Immunonogenetics laboratory. CCR5 was amplified from genomic DNA using gene specific primers. The presence or absence of the CCR $5 \Delta 32$ mutation was determined by relative size of the resulting PCR fragment. HLA-C single nucleotide polymorphism genotyping (rs9264942) was performed utilizing the Applied Biosystems 7300 real-time PCR System allelic discrimination assay, following the manufacturer's guidelines. Primers and probes were developed by Custom TaqMan SNP Genotyping assays (ABI). Determination of the HLA-B Bw4-80Ile allele was performed using the Olerup SSP 104.101 KIR Genotyping 12 Lot71E and 104.201 KIR ligand genotyping Lot85E kits, following the manufacturer's guidelines.

\section{$\mathrm{CD}^{+} \mathrm{T}$ cell susceptibility assay}

$\mathrm{CD}^{+} \mathrm{T}$ cells from the patient and five healthy donors were purified by negative selection using Miltenyi beads and were infected directly ex vivo. Spinoculation [55] 
was performed with pseudotyped CCR5 and CXCR4 tropic viruses and GFP expression was measured in triplicates as previously described [41,42]. Infection without spinoculation was also performed with CXCR4 tropic virus.

\section{Neutralization assay}

Neutralization assays were performed as described previously [43]. Briefly, recombinant pseudoviruses containing SF162, or Patient 169 env were titrated on TZM b1 cells to determine a linear range of infection for each pseudovirus. Infections were then performed in duplicate with a concentration of virus within this linear range, along with serial dilutions of patient plasma that had been heat inactivated at $56^{\circ} \mathrm{C}$ for $60 \mathrm{~min}$. All assays were performed in the presence of $10 \%$ total human plasma. Each virus was pre-incubated with 5\% test plasma and with four-fold serial dilutions of test plasma in normal human plasma. To determine neutralization, each test plasma well was compared to wells containing an equal concentration of normal human plasma.

\section{$\mathrm{CD}^{+} \mathrm{T}$ cell assays}

Reactive CTL epitopes were defined by IFN- $\gamma$ Elispot. As previously described [55], whole blood was taken from each patient and PBMCs were isolated by Ficoll gradient centrifugation. PBMCs were aliquoted into each well of 96 well MultiScreen (Millipore) plates with conjugated IFN- $\gamma$ antibody. Cells were activated with overlapping peptides spanning the entire amino acid sequence of $\mathrm{B}$ clade consensus gag and $n e f$ at a concentration of $5 \mu \mathrm{g} /$ $\mathrm{ml}$ (obtained from the NIH AIDS Research and Reference Program). PBMCs were cultured overnight, and subsequently analyzed. Quantification of spot forming units (SFU) was performed in a blinded fashion by Zellnet Consulting (Fort Lee, NJ). Positive responses were defined as greater than 50 SFU per million PBMCs. Negative controls (wells with medium alone) routinely had less than 15 SFU per million PBMC.

The effect of CD8+ T cells on autologous virus outgrowth was determined by measuring 24 values on unfractionated PBMC and PBMC depleted of CD8+ T cells. The cells were stimulated for 48 hours with PHA at $1 \mu \mathrm{g} / \mathrm{ml}$ and culture supernatant was obtained on day 10 .

The cytolytic $\mathrm{T}$ cell effect was determined by a CD8 suppression assay. PBMCs were isolated from patients, and $\mathrm{CD} 8^{+} \mathrm{T}$ cells were positively selected using Miltenyi magnetic beads (MACS, $\mathrm{CD}^{+} \mathrm{T}$ cell Isolation kit). $\mathrm{CD} 8$ ${ }^{+} \mathrm{T}$ cells were depleted of $\mathrm{CD} 16^{+}$cells (Invitrogen, Dynal Beads) to remove contaminating NK cells. CD ${ }^{+}$ $\mathrm{T}$ cells were isolated by negative selection using Miltenyi magnetic beads. Purity of depletion was analyzed by flow cytometry. $\mathrm{CD}^{+} \mathrm{T}$ cells were infected by spinoculation at $1200 \times \mathrm{g}$ for two hours with replication competent NL4-3 virus, in which GFP is engineered into nef. Flow cytometry was performed five days after infection to assess the percentage of GFP positive cells.

\section{Acknowledgements}

Supported by HHMI (RFS) and NIH grants R01Al056990-01A1 (JBM) and R01 Al080328 (JNB)

\section{Author details}

'Department of Medicine, Johns Hopkins University School of Medicine, Baltimore, Maryland 21287, USA. ²Department of Pathology, Johns Hopkins University School of Medicine, Baltimore, Maryland 21287, USA. ${ }^{3}$ Department of Molecular Microbiology and Immunology, Johns Hopkins Bloomberg School of Public Health, Baltimore, Maryland 21287, USA. ${ }^{4}$ Howard Hughes Medical Institute, Johns Hopkins University School of Medicine, Baltimore, Maryland 21287, USA.

\section{Authors' contributions}

MS, SAR, KOC, and RWB performed all the experiments and helped draft the manuscript. JRB helped to design the neutralization antibody assay. ARB, MAM, and WC tested plasma samples for antiretroviral drugs. AAC and JBM provided clinical samples and helped draft the manuscript. RFS participated in the study design and helped to draft the manuscript. JNB conceived of the study, participated in its design and coordination and helped to draft the manuscript. All authors read and approved the final manuscript.

\section{Competing interests}

The authors declare that they have no competing interests.

Received: 12 September 2011 Accepted: 5 December 2011 Published: 5 December 2011

\section{References}

1. O'Connell KA, Bailey JR, Blankson JN: Elucidating the elite: mechanisms of control in HIV-1 infection. Trends Pharmacol Sci 2009, 30:631-637.

2. Bailey JR, O'Connell K, Yang HC, Han Y, XU J, Jilek B, Williams TM, Ray SC, Siliciano RF, Blankson JN: Transmission of human immunodeficiency virus type 1 from a patient who developed AIDS to an elite suppressor. J Virol 2008, 82:7395-7410.

3. Blankson JN, Bailey JR, Thayil S, Yang HC, Lassen K, Lai J, Gandhi SK, Siliciano JD, Williams TM, Siliciano RF: Isolation and characterization of replication-competent human immunodeficiency virus type 1 from a subset of elite suppressors. J Virol 2007, 81:2508-2518.

4. Julg B, Pereyra F, Buzon MJ, Piechocka-Trocha A, Clark MJ, Baker BM, Lian J, Miura T, Martinez-Picado J, Addo MM, Walker BD: Infrequent recovery of HIV from but robust exogenous infection of activated CD4(+) T cells in HIV elite controllers. Clin Infect Dis 2010, 51:233-238.

5. Lamine A, Caumont-Sarcos A, Chaix ML, Saez-Cirion A, Rouzioux C, Delfraissy JF, Pancino G, Lambotte O: Replication-competent HIV strains infect HIV controllers despite undetectable viremia (ANRS EP36 study). AIDS 2007, 21:1043-1045.

6. Mens H, Kearney M, Wiegand A, Shao W, Schonning K, Gerstoft J, Obel N, Maldarelli F, Mellors JW, Benfield T, Coffin JM: HIV-1 continues to replicate and evolve in patients with natural control of HIV infection. J Virol 2010, 84:12971-12981.

7. O'Connell KA, Brennan TP, Bailey JR, Ray SC, Siliciano RF, Blankson JN: Control of HIV-1 in elite suppressors despite ongoing replication and evolution in plasma virus. J Virol 2010, 84:7018-7028.

8. Salgado M, Brennan TP, O'Connell KA, Bailey JR, Ray SC, Siliciano RF, Blankson JN: Evolution of the HIV-1 nef gene in HLA-B*57 positive elite suppressors. Retrovirology 2010, 7:94.

9. Emu B, Sinclair E, Hatano H, Ferre A, Shacklett B, Martin JN, McCune JM, Deeks SG: HLA Class I-Restricted T Cell Responses May Contribute to the Control of HIV Infection, but Such Responses are Not Always Necessary for Long-term Virus Control. J Virol 2008.

10. Han Y, Lai J, Barditch-Crovo P, Gallant JE, Williams TM, Siliciano RF, Blankson JN: The role of protective HCP5 and HLA-C associated polymorphisms in the control of HIV-1 replication in a subset of elite suppressors. AIDS 2008, 22:541-544. 
11. Lambotte O, Boufassa F, Madec Y, Nguyen A, Goujard C, Rouzioux L, Meyer C, Venet A, Delfraissy JF, SEROCO-HEMOCO Study Group: HIV controllers: a homogeneous group of HIV-1-infected patients with spontaneous control of viral replication. Clin Infect Dis 2005, 41:1053-1056.

12. Migueles SA, Sabbaghian MS, Shupert WL, Bettinotti MP, Marincola FM, Martino L, Hallahan CW, Selig SM, Schwartz D, Sullivan J, Connors M: HLA $B^{*} 5701$ is highly associated with restriction of virus replication in a subgroup of HIV-infected long term nonprogressors. Proc Natl Acad Sci USA 2000, 97:2709-2714.

13. Pereyra F, Addo MM, Kaufmann DE, Liu Y, Miura T, Rathod A, Baker B, Trocha A, Rosenberg R, Mackey E, Ueda P, Lu Z, Cohen D, Wrin T, Petropoulos CJ, Rosenberg ES, Walker BD: Genetic and immunologic heterogeneity among persons who control HIV infection in the absence of therapy. J Infect Dis 2008, 197:563-571.

14. Sajadi MM, Constantine NT, Mann DL, Charurat M, Dadzan E, Kadlecik P, Redfield RR: Epidemiologic characteristics and natural history of HIV-1 natural viral suppressors. J Acquir Immune Defic Syndr 2009, 50:403-408.

15. Betts MR, Nason MC, West SM, De Rosa SC, Migueles SA, Abraham J, Lederman MM, Benito JM, Goepfert PA, Connors M, Roederer M, Koup RA: HIV nonprogressors preferentially maintain highly functional HIV-specific CD8+ T cells. Blood 2006, 107:4781-4789.

16. Hersperger AR, Pereyra F, Nason M, Demers $K$, Sheth $P$, Shin LY, Kovacs CM, Rodriguez B, Sieg SF, Teixeira-Johnson L, Gudonis D, Goepfert PA, Lederman MM, Frank I, Makedonas G, Kaul R, Walker BD, Betts MR: Perforin expression directly ex vivo by HIV-specific CD8 T-cells is a correlate of HIV elite control. PLOS Pathog 2010, 6:e1000917.

17. Migueles SA, Laborico AC, Shupert WL, Sabbaghian MS, Rabin R, Hallahan CW, Van Baarle D, Kostense S, Miedema F, McLaughlin M, Ehler L, Metcalf J, Liu S, Connors M: HIV-specific CD8+ T cell proliferation is coupled to perforin expression and is maintained in nonprogressors. Nat Immunol 2002, 3:1061-1068.

18. Migueles SA, Osborne CM, Royce C, Compton AA, Joshi RP, Weeks KA, Rood JE, Berkley AM, Sacha JB, Cogliano-Shutta NA, Lloyd M, Roby G, Kwan R, McLaughlin M, Stallings S, Rehm C, O'Shea MA, Mican J, Packard BZ, Komoriya A, Palmer S, Wiegand AP, Maldarelli F, Coffin JM, Mellors JW, Hallahan CW, Follman DA, Connors M: Lytic granule loading of CD8+ T cells is required for HIV-infected cell elimination associated with immune control. Immunity 2008, 29:1009-1021.

19. Saez-Cirion A, Lacabaratz C, Lambotte O, Versmisse P, Urrutia A, Boufassa F, Barre-Sinoussi F, Delfraissy JF, Sinet M, Pancino G, Venet A, Agence Nationale de Recherches sur le Sida EP36 HIV Controllers Study Group: HIV controllers exhibit potent CD8 T cell capacity to suppress HIV infection ex vivo and peculiar cytotoxic T lymphocyte activation phenotype. Proc Natl Acad Sci USA 104:6776-6781.

20. Rosenberg ES, Altfeld M, Poon SH, Phillips MN, Wilkes BM, Eldridge RL Robbins GK, D'Aquila RT, Goulder PJ, Walker BD: Immune control of HIV-1 after early treatment of acute infection. Nature 2000, 407:523-526.

21. Kaufmann DE, Lichterfeld M, Altfeld M, Addo MM, Johnston MN, Lee PK, Wagner BS, Kalife ET, Strick D, Rosenberg ES, Walker BD: Limited durability of viral control following treated acute HIV infection. PLoS Med 2004, 1: e36.

22. Margolick JB, Imteyaz H, Gallant JE, Langan SJ, Dinoso JB, Siliciano J, Blankson J, Nilles TL, Smith KA, Apuzzo LG: Prolonged viral suppression without therapy in an HIV-1 seroconverter following early antiretroviral therapy and daily interleukin-2. AIDS 2010, 24:932-935.

23. Hocqueloux L, Prazuck T, Avettand-Fenoel V, Lafeuillade A, Cardon B, Viard JP, Rouzioux C: Long-term immunovirologic control following antiretroviral therapy interruption in patients treated at the time of primary HIV-1 infection. AIDS 2010, 24:1598-1601.

24. Blankson JN: Primary HIV-1 infection: to treat or not to treat? AIDS Read 2005, 15:245-6, 249-51.

25. Smith DE, Walker BD, Cooper DA, Rosenberg ES, Kaldor JM: Is antiretroviral treatment of primary HIV infection clinically justified on the basis of current evidence? AIDS 2004, 18:709-718.

26. Bell SK, Little SJ, Rosenberg ES: Clinical management of acute HIV infection: best practice remains unknown. J Infect Dis 2010, 202(Suppl 2):S278-88.

27. Blankson JN, Finzi D, Pierson TC, Sabundayo BP, Chadwick K, Margolick JB, Quinn TC, Siliciano RF: Biphasic decay of latently infected CD4+ T cells in acute human immunodeficiency virus type 1 infection. J Infect Dis 2000, 182:1636-1642.
28. Dinoso JB, Kim SY, Siliciano RF, Blankson JN: A comparison of viral loads between HIV-1-infected elite suppressors and individuals who receive suppressive highly active antiretroviral therapy. Clin Infect Dis 2008, 47:102-104.

29. Palmer S, Wiegand AP, Maldarelli F, Bazmi H, Mican JM, Polis M, Dewar RL, Planta A, Liu S, Metcalf JA, Mellors JW, Coffin JM: New real-time reverse transcriptase-initiated PCR assay with single-copy sensitivity for human immunodeficiency virus type 1 RNA in plasma. J Clin Microbiol 2003, 41:4531-4536.

30. Finzi D, Blankson J, Siliciano JD, Margolick JB, Chadwick K, Pierson T, Smith K, Lisziewicz J, Lori F, Flexner C, Quinn TC, Chaisson RE, Rosenberg E, Walker B, Gange S, Gallant J, Siliciano RF: Latent infection of CD4+ T cells provides a mechanism for lifelong persistence of HIV-1, even in patients on effective combination therapy. Nat Med 1999, 5:512-517.

31. Siliciano JD, Kajdas J, Finzi D, Quinn TC, Chadwick K, Margolick JB, Kovacs C, Gange SJ, Siliciano RF: Long-term follow-up studies confirm the stability of the latent reservoir for HIV-1 in resting CD4+ T cells. Nat Med 2003, 9:727-728.

32. Zhang H, Zhou Y, Alcock C, Kiefer T, Monie D, Siliciano J, Li Q, Pham P, Cofrancesco J, Persaud D, Siliciano RF: Novel single-cell-level phenotypic assay for residual drug susceptibility and reduced replication capacity of drug-resistant human immunodeficiency virus type 1. J Virol 2004, 78:1718-1729.

33. Huang $Y$, Paxton WA, Wolinsky SM, Neumann AU, Zhang L, He T, Kang S, Ceradini D, Jin Z, Yazdanbakhsh K, Kunstman K, Erickson D, Dragon E, Landau NR, Phair J, Ho DD, Koup RA: The role of a mutant CCR5 allele in HIV-1 transmission and disease progression. Nat Med 1996, 2:1240-1243.

34. Ashton L, Biti RA, Ffrench RA, Bennetts BH, Newcombe NR, Benson EM, Carr A, Cooper DA, Kaldor JM: Increased frequency of CCR-5 delta 32 heterozygotes among long-term non-progressors with HIV-1 infection. The Australian Long-Term Non-Progressor Study Group. AIDS 1997, 11:1833-1838

35. International HIV Controllers Study, Pereyra F, Jia X, McLaren PJ, Telenti A, de Bakker PI, Walker BD, Ripke S, Brumme CJ, Pulit SL, Carrington M, Kadie CM, Carlson JM, Heckerman D, Graham RR, Plenge RM, Deeks SG, Gianniny L, Crawford G, Sullivan J, Gonzalez E, Davies L, Camargo A, Moore JM, Beattie N, Gupta S, Crenshaw A, Burtt NP, Guiducci C, Gupta N, Gao X, Qi Y, Yuki Y, Piechocka-Trocha A, Cutrell E, Rosenberg R, Moss KL, Lemay P, O'Leary J, Schaefer T, Verma P, Toth I, Block B, Baker B, Rothchild A, Lian J, Proudfoot J, Alvino DM, Vine S, Addo MM, Allen TM, Altfeld M, Henn MR, Le Gall S, Streeck H, Haas DW, Kuritzkes DR, Robbins GK, Shafer RW, Gulick RM, Shikuma CM, Haubrich R, Riddler S, Sax PE, Daar ES, Ribaudo HJ, Agan B, Agarwal S, Ahern RL, Allen BL, Altidor S, Altschuler EL, Ambardar S, Anastos K, Anderson B, Anderson V, Andrady U, Antoniskis D, Bangsberg D, Barbaro D, Barrie W, Bartczak J, Barton S, Basden P, Basgoz N, Bazner S, Bellos NC, Benson AM, Berger J, Bernard NF, Bernard AM, Birch C, Bodner SJ, Bolan RK, Boudreaux ET, Bradley M, Braun JF, Brndjar JE, Brown SJ, Brown K, Brown ST, Burack J, Bush LM, Cafaro V, Campbell O, Campbell J, Carlson RH, Carmichael JK, Casey KK, Cavacuiti C, Celestin G, Chambers ST, Chez N, Chirch LM, Cimoch PJ, Cohen D, Cohn LE, Conway B, Cooper DA, Cornelson B, Cox DT, Cristofano MV, Cuchural G Jr, Czartoski JL, Dahman JM, Daly JS, Davis BT, Davis K, Davod SM, DeJesus E, Dietz CA, Dunham E, Dunn ME, Ellerin TB, Eron JJ, Fangman JJ, Farel CE, Ferlazzo H, Fidler S, Fleenor-Ford A, Frankel R, Freedberg KA, French NK, Fuchs JD, Fuller JD, Gaberman J, Gallant JE, Gandhi RT, Garcia E, Garmon D, Gathe JC Jr, Gaultier CR, Gebre W, Gilman FD, Gilson I, Goepfert PA, Gottlieb MS, Goulston C, Groger RK, Gurley TD, Haber S, Hardwicke R, Hardy WD, Harrigan PR, Hawkins TN, Heath S, Hecht FM, Henry WK, Hladek M, Hoffman RP, Horton JM, Hsu RK, Huhn GD, Hunt P, Hupert MJ, Illeman ML, Jaeger H, Jellinger RM, John M, Johnson JA, Johnson $\mathrm{KL}$, Johnson $\mathrm{H}$, Johnson $\mathrm{K}$, Joly J, Jordan WC, Kauffman CA, Khanlou H, Killian RK, Kim AY, Kim DD, Kinder CA, Kirchner JT, Kogelman L, Kojic EM, Korthuis PT, Kurisu W, Kwon DS, LaMar M, Lampiris H, Lanzafame M, Lederman MM, Lee DM, Lee JM, Lee MJ, Lee ET, Lemoine J, Levy JA, Llibre JM, Liguori MA, Little SJ, Liu AY, Lopez AJ, Loutfy MR, Loy D, Mohammed DY, Man A, Mansour MK, Marconi VC, Markowitz M, Marques R, Martin JN, Martin HL Jr, Mayer KH, McElrath MJ, McGhee TA, McGovern BH, McGowan K, McIntyre D, Mcleod GX, Menezes P, Mesa G, Metroka CE, Meyer-Olson D, Miller AO, Montgomery K, Mounzer KC, Nagami EH, Nagin I, Nahass RG, Nelson MO, Nielsen C, Norene DL, O'Connor DH, Ojikutu BO, Okulicz J, Oladehin OO, Oldfield EC, 
Olender SA, Ostrowski M, Owen WF Jr, Pae E, Parsonnet J, Pavlatos AM, Perlmutter AM, Pierce MN, Pincus JM, Pisani L, Price LJ, Proia L, Prokesch RC, Pujet HC, Ramgopal M, Rathod A, Rausch M, Ravishankar J, Rhame FS, Richards CS, Richman DD, Rodes B, Rodriguez M, Rose RC, Rosenberg ES, Rosenthal D, Ross PE, Rubin DS, Rumbaugh E, Saenz L, Salvaggio MR, Sanchez WC, Sanjana VM, Santiago S, Schmidt W, Schuitemaker H, Sestak PM, Shalit P, Shay W, Shirvani VN, Silebi VI, Sizemore JM Jr, Skolnik PR, Sokol-Anderson M, Sosman JM, Stabile P, Stapleton JT, Starrett S, Stein F, Stellbrink HJ, Sterman FL, Stone VE, Stone DR, Tambussi G, Taplitz RA, Tedaldi EM, Telenti A, Theisen W, Torres R, Tosiello L, Tremblay C, Tribble MA, Trinh PD, Tsao A, Ueda P, Vaccaro A, Valadas E, Vanig TJ, Vecino I, Vega VM, Veikley W, Wade BH, Walworth C, Wanidworanun C, Ward DJ, Warner DA, Weber RD, Webster D, Weis S, Wheeler DA, White DJ, Wilkins E, Winston A, Wlodaver CG, van't Wout A, Wright DP, Yang OO, Yurdin DL, Zabukovic BW, Zachary KC, Zeeman B, Zhao M: The major genetic determinants of HIV-1 control affect HLA class I peptide presentation. Science 2010, 330:1551-1557.

36. Shianna KV, Ge D, Colombo S, Ledergerber B, Weale M, Zhang K, Gumbs C, Castagna A, Cossarizza A, Cozzi-Lepri A, De Luca A, Easterbrook P, Francioli P, Mallal S, Martinez-Picado J, Miro JM, Obel N, Smith JP, Wyniger J, Descombes P, Antonarakis SE, Letvin NL, McMichael AJ, Haynes BF, Telenti A, Goldstein DB: A whole-genome association study of major determinants for host control of HIV-1. Science 2007, 317:944-947.

37. Martin MP, Gao X, Lee JH, Nelson GW, Detels R, Goedert JJ, Buchbinder S, Hoots K, Vlahov D, Trowsdale J, Wilson M, O'Brien SJ, Carrington M: Epistatic interaction between KIR3DS1 and HLA-B delays the progression to AIDS Nat. Genet 2002, 31:429-434.

38. Martin MP, Qi Y, Gao X, Yamada E, Martin JN, Pereyra F, Colombo S, Brown EE, Shupert WL, Phair J, Goedert JJ, Buchbinder S, Kirk GD, Telenti A, Connors M, O'Brien SJ, Walker BD, Parham P, Deeks SG, McVicar DW, Carrington M: Innate partnership of HLA-B and KIR3DL1 subtypes against HIV-1. Nat Genet 2007, 39:733-740.

39. Chen H, Li C, Huang J, Cung T, Seiss K, Beamon J, Carrington MF, Porter LC, Burke PS, Yang Y, Ryan BJ, Liu R, Weiss RH, Pereyra F, Cress WD, Brass AL, Rosenberg ES, Walker BD, Yu XG, Lichterfeld M: CD4+ T cells from elite controllers resist HIV-1 infection by selective upregulation of p21. J Clin Invest 2011, 121:1549-1560.

40. Saez-Cirion A, Hamimi C, Bergamaschi A, David A, Versmisse P, Melard A, Boufassa F, Barre-Sinoussi F, Lambotte O, Rouzioux C, Pancino G, for the ANRS CO18 Cohort: Restriction of HIV-1 replication in macrophages and CD4+ T cells from HIV controllers. Blood 2011, 118:955-964.

41. O'Connell KA, Rabi SA, Siliciano RF, Blankson JN: CD4+ T cells from elite suppressors are more susceptible to HIV-1 but produce fewer virions than cells from chronic progressors. Proc Natl Acad Sci USA 2011.

42. Rabi SA, O'Connell KA, Nikolaeva D, Bailey JR, Jilek BL, Shen L, Page KR, Siliciano RF, Blankson JN: Unstimulated primary CD4+ T cells from HIV-1positive elite suppressors are fully susceptible to HIV-1 entry and productive infection. J Virol 2011, 85:979-986.

43. Bailey JR, Lassen KG, Yang HC, Quinn TC, Ray SC, Blankson JN, Siliciano RF: Neutralizing antibodies do not mediate suppression of human immunodeficiency virus type 1 in elite suppressors or selection of plasma virus variants in patients on highly active antiretroviral therapy. $J$ Virol 2006, 80:4758-4770.

44. Brockman MA, Schneidewind A, Lahaie M, Schmidt A, Miura T, Desouza I, Ryvkin F, Derdeyn CA, Allen S, Hunter E, Mulenga J, Goepfert PA, Walker BD, Allen TM: Escape and compensation from early HLA-B57-mediated cytotoxic T-lymphocyte pressure on human immunodeficiency virus type $1 \mathrm{Gag}$ alter capsid interactions with cyclophilin. A J Virol 2007, 81:12608-12618.

45. Leslie AJ, Pfafferott KJ, Chetty P, Draenert R, Addo MM, Feeney M, Tang Y, Holmes EC, Allen T, Prado JG, Altfeld M, Brander C, Dixon C, Ramduth D, Jeena P, Thomas SA, St John A, Roach TA, Kupfer B, Luzzi G, Edwards A, Taylor G, Lyall H, Tudor-Williams G, Novelli V, Martinez-Picado J, Kiepiela P, Walker BD, Goulder PJ: HIV evolution: CTL escape mutation and reversion after transmission. Nat Med 2004, 10:282-289.

46. Martinez-Picado J, Prado JG, Fry EE, Pfafferott K, Leslie A, Chetty S, Thobakgale C, Honeyborne I, Crawford H, Matthews P, Pillay T, Rousseau C, Mullins II, Brander C, Walker BD, Stuart DI, Kiepiela P, Goulder P: Fitness cost of escape mutations in p24 Gag in association with control of human immunodeficiency virus type 1. J Virol 2006, 80:3617-3623.
47. Raymond S, Delobel P, Mavigner M, Cazabat M, Encinas S, Souyris C, Bruel P, Sandres-Saune K, Marchou B, Massip P, Izopet J: CXCR4-using viruses in plasma and peripheral blood mononuclear cells during primary HIV-1 infection and impact on disease progression. AIDS 2010, 24:2305-2312.

48. Yu XF, Wang Z, Vlahov D, Markham RB, Farzadegan H, Margolick JB: Infection with dual-tropic human immunodeficiency virus type 1 variants associated with rapid total T cell decline and disease progression in injection drug users. J Infect Dis 1998, 178:388-396.

49. Vanhems P, Lambert J, Cooper DA, Perrin L, Carr A, Hirschel B, Vizzard J, Kinloch-de Loes S, Allard R: Severity and prognosis of acute human immunodeficiency virus type 1 illness: a dose-response relationship. Clin Infect Dis 1998, 26:323-329.

50. Altfeld M, Addo MM, Rosenberg ES, Hecht FM, Lee PK, Vogel M, Yu XG, Draenert R, Johnston MN, Strick D, Allen TM, Feeney ME, Kahn JO, Sekaly RP, Levy JA, Rockstroh JK, Goulder PJ, Walker BD: Influence of HLAB57 on clinical presentation and viral control during acute HIV-1 infection. AIDS 2003, 17:2581-2591.

51. Goujard C, Chaix ML, Lambotte O, Deveau C, Sinet M, Guergnon J, Courgnaud V, Rouzioux C, Delfraissy JF, Venet A, Meyer L, Agence Nationale de Recherche sur le Sida PRIMO Study Group: Spontaneous control of viral replication during primary HIV infection: when is "HIV controller" status established? Clin Infect Dis 2009, 49:982-986.

52. Okulicz JF, Marconi VC, Landrum ML, Wegner S, Weintrob A, Ganesan A, Hale B, Crum-Cianflone N, Delmar J, Barthel V, Quinnan G, Agan BK, Dolan MJ, Infectious Disease Clinical Research Program (IDCRP) HIV Working Group: Clinical outcomes of elite controllers, viremic controllers, and long-term nonprogressors in the US Department of Defense HIV natural history study. J Infect Dis 2009, 200:1714-1723.

53. Saez-Cirion $A$, Sinet $M$, Shin SY, Urrutia A, Versmisse P, Lacabaratz $C$, Boufassa F, Avettand-Fenoel V, Rouzioux C, Delfraissy JF, Barre-Sinoussi F, Lambotte O, Venet A, Pancino G, ANRS EP36 HIV Controllers Study Group: Heterogeneity in HIV suppression by CD8 T cells from HIV controllers: association with Gag-specific CD8 T cell responses. J Immunol 2009, 182:7828-7837.

54. O'Doherty U, Swiggard WJ, Malim MH: Human immunodeficiency virus type 1 spinoculation enhances infection through virus binding. J Virol 2000, 74:10074-10080.

55. O'Connell KA, Xu J, Durbin AP, Apuzzo LG, Imteyaz H, Williams TM, Ray SC, Margolick JB, Siliciano RF, Blankson JN: HIV-1 evolution following transmission to an HLA-B*5801-positive patient. J Infect Dis 2009, 200:1820-1824.

doi:10.1186/1742-4690-8-97

Cite this article as: Salgado et al:: Prolonged control of replicationcompetent dual- tropic human immunodeficiency virus-1 following cessation of highly active antiretroviral therapy. Retrovirology 2011 8:97.

\section{Submit your next manuscript to BioMed Central and take full advantage of:}

- Convenient online submission

- Thorough peer review

- No space constraints or color figure charges

- Immediate publication on acceptance

- Inclusion in PubMed, CAS, Scopus and Google Scholar

- Research which is freely available for redistribution

Submit your manuscript at www.biomedcentral.com/submit
C Biomed Central 